\title{
The cave millipede Tracbysphaera fragilis Golovatch, 1976, new to the fauna of Ablkhazia, western Caucasus (Diplopoda: Glomerida: Glomeridae)
}

\author{
Пешерная диплопода Trachysphaera fragilis Golovatch, 1976, \\ новая дмя фауны Абхазии (Западный Кавказ) \\ (Diplopoda: Glomerida: Glomeridae)
}

\author{
Sergei I. Golovatch ${ }^{1}$, Ilya S. Turbanov ${ }^{2}$ \\ С.И. Головач, И.С. Турбанов
}

\footnotetext{
${ }^{1}$ The Severtsov Institute for Problems of Ecology and Evolution, Russian Academy of Sciences, Moscow 119071, Russia. E-mail: sgolovatch@yandex.ru

Институт проблем экологии и эволюции РАН, Ленинский проспект 33, Москва 119071, Россия.

${ }^{2}$ The Papanin Institute of the Biology of Inland Waters, Russian Academy of Sciences, Borok, Yaroslavl Region 152742, Russia. E-mail: turba13@mail.ru

Институт биологии внутренних вод имени И.Д. Папанина РАН, Ярославская обл., Борок 152742, Россия.
}

\begin{abstract}
KEY WORDS. Trachysphaera fragilis, cave, western Georgia, Abkhazia.
КЛЮЧЕВЫЕ СЛОВА. Trachysphaera fragilis, пещера, Западная Грузия, Абхазия.
\end{abstract}

ABSTRACT. The most likely troglobiont species Trachysphaera fragilis Golovatch, 1976, hitherto known only from several karst caves in western Georgia, Caucasus, is recorded in Abkhazia for the first time. The new samples come from two caves in the Sukhum District, both stem from the deepest parts of their caves.

РЕЗЮМЕ. Очень вероятно троглобионтный вид Trachysphaera fragilis Golovatch, 1976, до сих пор известный лишь из нескольких карстовых пещер в Западной Грузии (Кавказ), впервые отмечается в Абхазии. Новые пробы собраны в двух пещерах в Сухумском районе, найдены в самых удалённых от входа частях пещер.

The Euro-Mediterranean genus Trachysphaera Heller, 1857 , is one of the most speciose in the family Glomeridae, at present encompassing about 30 species ranging across Europe, except for its northern and eastern parts, in the Crimea, the Caucasus, Turkey and northwestern Iran [Minelli, 2015]. Several species are presumed or proven troglobionts, including a few from western Georgia, Caucasus [Barjadze et al., 2015]. One such species is T. fragilis Golovatch, 1976, described and hitherto known only from a number of karst caves near Tshhaltubo, Kutaisi and Gegechkori (now Martvili), namely, the caves Ghliana (= Gliana), Kumistavi, Motena, Orpiri II, Prometheus, Sataplia I, Sataplia II, Sataplia IV, Solkota and Tetra [Golovatch, 1976, 1981, 1984/1985, 1990; Barjadze et al., 2015]. The species shows several traits of troglomorphism (unpigmented body and ocelli, a thin, often nearly translucent and fragile tegument, and an elongated antennomere 6), has never been collected be- yond caves and therefore may be regarded as a triglobiont rather than a troglophile [cf. Turbanov et al., 2016].

The present note puts on record $T$. fragilis from another two caves, this time in Abkhazia. The new samples, all taken by the second author, appear to be quite remote from the terra typica (Sataplia I Cave) in western Georgia. Because both come from the deepest, dark parts of their caves, they most likely represent true troglobiont populations, while the species is new to the fauna of Abkhazia.

The new material is housed in the collection of the Zoological Museum, State University of Moscow, Russia (ZMUM + acquisition number).

Trachysphaera fragilis Golovatch, 1976 Figs 1-6.

MATERIAL. 14 ex. ( $\bigcirc^{7} \bigcirc^{7}$, 오, juv.) (ZMUM $\left.\rho 3518\right)$, Western Caucasus, Abkhazia, Sukhum Distr., near Verkhnie Eshery, Adzaba Cave, $>100 \mathrm{~m}$ off the entrance, 14.IX.2014, leg. I.S. Turbanov; 1 우 (ZMUM 03517 ), Abkhazia, Sukhum Distr., near Guma, Mikhailovskaya Cave, ca $80 \mathrm{~m}$ off the entrance, 3.IX.2015, leg. I.S. Turbanov.

REMARKS. The new illustrations are provided to document the species identity. The fresh samples are in complete agreement with the original description [Golovatch, 1976].

ACKNOWLEDGEMENTS. The second author is most grateful to A.G. Koval (All-Russia Research Institute of Plant Protection, St. Petersburg, Russia) and R.S. Vargovitsh (Institute of Zoology, National Academy of Sciences, Kiev, Ukraine) for the help rendered during his field-work in Abkhazia. His research was partly supported through grants Nos 16-34-00275 мол_a and No. 15-34-40011 Абх_a, both received from the Russian Foundation for Basic Research. Kirill Makarov very skillfully took all colour pictures. Both Kirill Mikhailov and Elena Kudryavtseva (ZMUM) helped us incorporate the ZMUM samples into the collection. 


\section{References}

Barjadze S., Murvanidze M., Arabuli T., Mumladze L., Pkhakadze V., Djanashvili R., Salakaia M. 2015. Annotated list of invertebrates of the Georgian karst caves. Tbilisi: Georgian Academic Book. 120 p.

Golovatch S.I. 1976. [Description of new species of Trachysphaera (Oniscomorpha; Diplopoda) from caves of western Transcaucasia with notes on T. rotundata (Lignau) 1911] // Bulletin de la Société

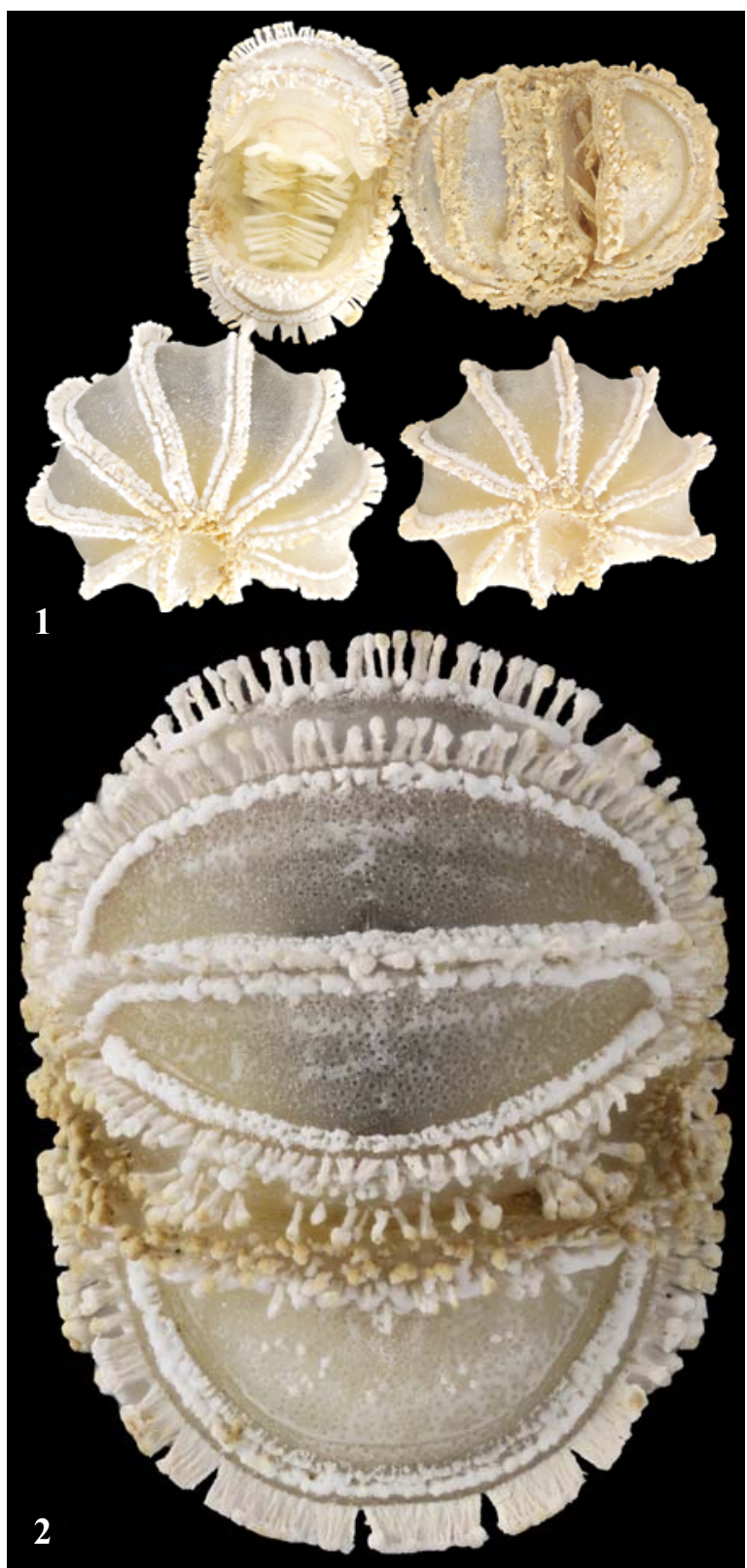

Figs 1-2. Trachysphaera fragilis Golovatch, 1976, specimens from Cave Adzaba: 1 - habituses of four specimens in various aspects; 2 - enlarged habitus of a rolled-up specimen, ventral view. Pictures by K.V. Makarov, taken not to scale.

Рис. 1-2. Trachysphaera fragilis Golovatch, 1976, экземплярь из пещеры Адзаба: 1 - обший вид четырех экземпляров в разных положениях; 2 - увеличенный общий вид свернутого экземпляра, вид снизу. Фотографии К.В. Макарова, снято без масштаба des Naturalistes de Moscou, section Biologique. Vol.81. No.5. P.30-43 [in Russian]

Golovatch S.I. 1981. [A review of the cavernicolous fauna of millipedes (Diplopoda) of the western Caucasus] // Caves of Georgia. No.9. P.108-111 [in Russian].

Golovatch S.I. 1984/1985. Two new genera of cave-dwelling millipedes (Diplopoda), with remarks on the millipede fauna of West Caucasian caves // International Journal of Speleology. Vol.14. P.39-50.

Golovatch S.I. 1990. Diplopoda of the Caucasus. 3. Trachysphaeridae, with contributions to the fauna of Turkey // Senckenbergiana biologica. Bd.70. H.4/6. S.331-358.

Minelli A. (ed.). 2015. Treatise on Zoology - Anatomy, Taxonomy, Biology. The Myriapoda. Vol.2. Leiden-Boston: Brill. 482 p.

Turbanov I.S., Palatov D.M., Golovatch S.I. 2016. [The state of the art of biospeleology in Russia and other countries of the former Soviet Union: A review of cave (endogean) invertebrate fauna. 2. Arachnida - Acknowledgements] // Zoologicheskii zhurnal. Vol.95. No.11. P.1283-1304 [in Russian].
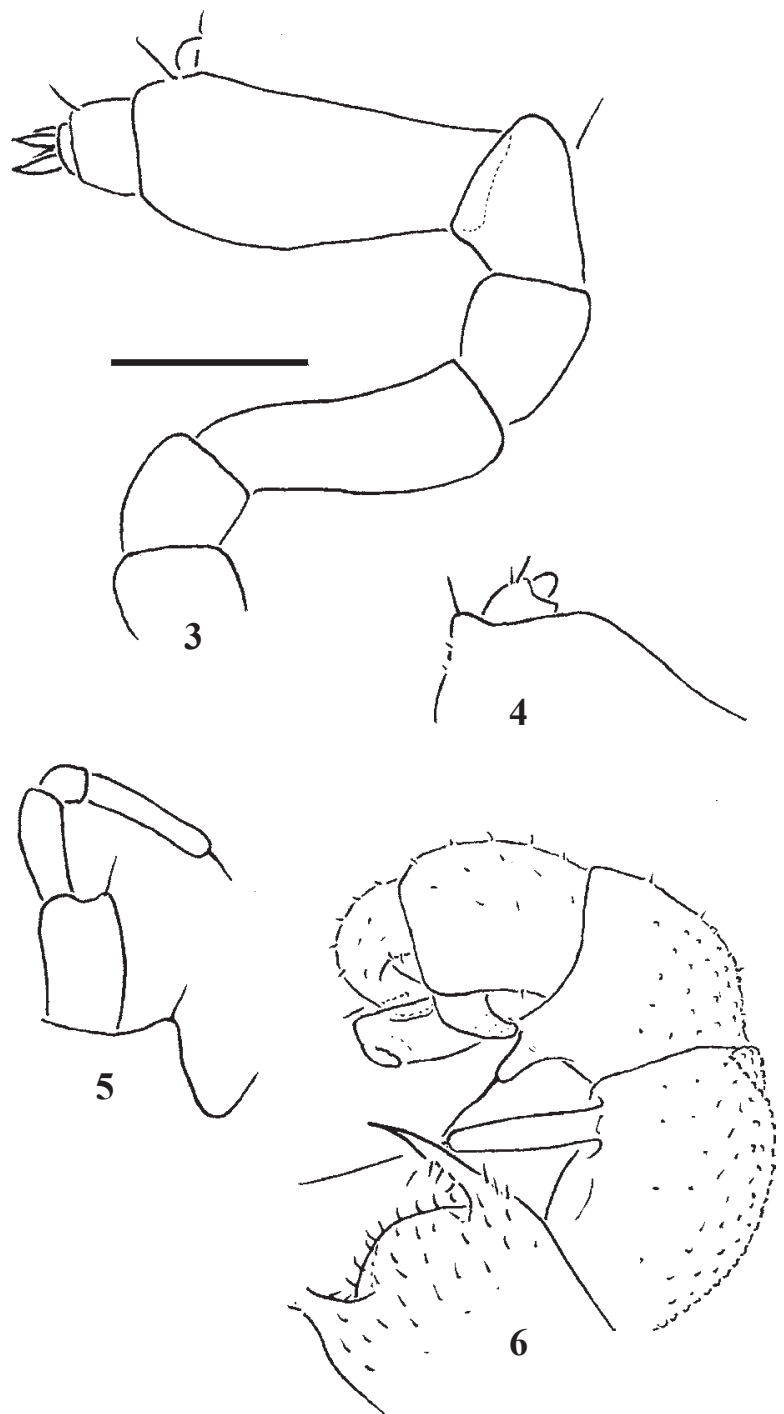

Figs 3-6. Trachysphaera fragilis Golovatch, 1976, or from Cave Adzaba: 3 - antenna, lateral view; 4 - right leg 17, caudal view; 5-right leg 18, oral view; 6 - right telopod (leg 19), oral view. Scale bar: $0.2 \mathrm{~mm}$.

Рис. 3-6. Trachysphaera fragilis Golovatch, 1976, О7 из пещеры Адзаба: 3 - усик, сбоку; 4 - правая нога 17, сзади; 5 - правая нога 18, спереди; 6 - правый телопод (нога 19), спереди. Масштаб: 0,2 мм. 